\title{
Model Pembelajaran Artikulasi dengan Metode Bimbingan Individu dan Kelompok Untuk Meningkatkan Prestasi Belajar IPA Siswa
}

\author{
I Ketut Jingga ${ }^{1}$ \\ 1SMP Negeri 2 Blahbatuh, \\ Gianyar, Indonesia \\ email: ketutjingga071@gmail.com
}

\begin{abstract}
Abstrak
Penelitian ini dilaksanakan di SMP Negeri 2 Blahbatuh dengan tujuan untuk meningkatkan prestasi belajar IPA siswa kelas VII F SMP Negeri 2 Blahbatuh melalui penerapan model pembelajaran Artikulasi dengan metode bimbingan individu dan kelompok. Subjek penelitian ini adalah siswa kelas VII F SMP Negeri 2 Blahbatuh yang berjumlah 39 orang, dalam mata pelajaran IPA. Data tentang prestasi belajar siswa diperoleh dengan menggunakan metode tes dengan instrumanya yaitu berupa tes prestasi belajar. Data tersebut kemudian dianalisis dengan menggunakan teknik analisis deskriptif kuantitatif. Hasil penelitian ini adalah sebagai berikut (1) penerapan model pembelajaran Artikulasi dengan metode bimbingan individu dan kelompok dapat meningkatkan prestasi belajar IPA siswa kelas VII F pada semester II SMP Negeri 2 Blahbatuh tahun pelajaran 2019/2020. Skor rata-rata prestasi belajar siswa menunjukkan adanya peningkatan dari awal pembelajaran, ke siklus I, hingga ke siklus II. Rata-rata kelas prestasi belajar pada awal pembelajaran hanya mencapai 62,82 , siklus I meningkat menjadi 72,30 pada siklus II menjadi 82,69 . Ketuntasan klaksikal awal hanya mencapai $28,20 \%$, pada siklus I meningkat menjadi $68,97 \%$ dan pada siklus II menjadi $100 \%$.
\end{abstract}

Kata Kunci: Model Pembelajaran Artikulasi, Metode Bimbingan Individu Dan Kelompok, Prestasi Belajar.

\begin{abstract}
This research was conducted at SMP Negeri 2 Blahbatuh with the aim of improving the science learning achievement of students of class VII F SMP Negeri 2 Blahbatuh through the application of the Articulation learning model with individual and group guidance methods. The subjects of this study were 39 students of class VII F SMP Negeri 2 Blahbatuh, in science subjects. Data on student achievement were obtained using the test method with the instrument in the form of a learning achievement test. The data is then analyzed using quantitative descriptive analysis techniques. The results of this study are as follows (1) the application of the Articulation learning model with the individual and group guidance method can improve the science learning achievement of class VII F students in the second semester of SMP Negeri 2 Blahbatuh in the 2019/2020 academic year. The average score of student learning achievement shows an increase from the beginning of learning, to cycle I, to cycle II. The class average of learning achievement at the beginning of learning only reached 62.82 , the first cycle increased to 72.30 in the second cycle to 82.69 . Initial classical completeness only reached $28.20 \%$, in cycle I it increased to $68.97 \%$ and in cycle II it became $100 \%$.
\end{abstract}

Keywords: Articulation Learning Model, Individual and Group Guidance Methods, Learning Achievement.

\section{Pendahuluan}

Keberhasilan proses pembelajaran lebih banyak ditentukan oleh kemampuan guru dalam mengelola proses pembelajaran tersebut. Kadang ada guru yang disebut pintar tetapi lemah dalam menyampaikan pengetahuan dan pemahaman yang ada dalam dirinya maka

\footnotetext{
${ }^{*}$ Corresponding author.
}

Received 03 Februari 2020; Accepted 31 July 2020; Available online 1 September 2020

(c) 2020 MPI. All Rights Reserved 
tentu proses pembelajaran tidak akan berhasil dengan baik. Kadang ada guru yang disebut tidak terlalu pintar tetapi dalam menyampaikan dan mengelola pembelajaran lebih kreatif dan memahami cara penyampaiannya bisa jadi menyebabkan proses pembelajaran akan berhasil dengan baik. Di antara keduanya tentu yang paling sesuai adalah memiliki kemampuan profesionalisme keguruan dan mampu menyampaikan dengan baik demi terciptanya proses dan tujuan pembelajaran yang diharapkan untuk mampu meningkatkan ketakwaan terhadap Tuhan Yang Maha Esa.

Untuk dapat membelajarkan siswa sesuai apa yang diharapkan, guru harus didukung dengan pengetahuan dan pemahaman standar yang mesti dikuasai sesuai metodik dan didaktik, agar dapat mengelola secara profesional mata pelajaran yang diampunya. Kompetensi pedagogik yang dimaksud menurut (Mulyasa, 2011) sekurang-kurangnya meliputi: a) pemahaman wawasan atau landasan kependidikan; b) pemahaman terhadap peserta didik; c) pengembangan kurikulum/silabus; d) perancangan pembelajaran; e) pelaksanaan pembelajaran yang mendidik dan dialogis; f) pemanfaatan teknologi pembelajaran; g) evaluasi hasil belajar; dan $h$ ) pengembangan peserta didik untuk mengaktualisasikan berbagai potens yang dimilikinya.

Wardani dan Julaeha (Modul IDIK, 4307) mempersyaratkan 7 keterampilan yang mesti dikuasai guru dalam melaksanakan pembelajaran, untuk dapat disebut professional yaitu: 1) keterampilan bertanya, 2) keterampilan memberi penguatan, 3) keterampilan mengadakan variasi, 4) keterampilan menjelaskan, 5) keterampilan membuka dan menutup pelajaran, 6) keterampilan membimbing diskusi, 7) keterampilan mengelola kelas. Keterampilanketerampilan ini berhubung dengan kemampuan guru untuk menguasai dasar-dasar pengetahuan yang berhubungan dengan persiapan dan pelaksanaan proses pembelajaran yang akan memberikan dukungan terhadap cara berpikir siswa yang kreatif dan imajinatif.

Namun dilapangan masih banyak kelemahan guru di dalam melaksanakan proses pembelajaran. Guru hanya bercerita di kelas dengan deskripsi yang kurang jelas tentang materi pembelajaran. Guru kurang memberikan kesempatan kepada siswa untuk berkembang sesuai dengan kemampuannya. Pembelajaran selalu berpusat pada guru sehingga siswa menjadi fasif atau kurang aktif. Pada akhirnya siswa kurang termotivasi untuk belajar sehingga kecerdasan siswa tidak sesuai dengan apa yang diharapkan.

Menyadari permasalahan yang sedang dihadapi, untuk mendukung semua yang telah dijelaskan di atas. Guru selaku peneliti yang bertugas di SMP Negeri 2 Blahbatuh mencoba melakukan koreksi dan refleksi atas prestasi belajar awal siswa kelas VII F semester II tahun pelajaran 2019/2020 yang ditemukan pada saat observasi. Rata-rata nilai mata pelajaran IPA siswa yang diperoleh hanya mencapai 62,82 dengan prosentase ketuntasan belajar sebesar $28,20 \%$. Nilai tersebut ternyata masih jauh dari Kriteria Ketuntasan Minimal (KKM) yang ditetapkan sekolah yaitu 73,00.

Untuk mengatasi persoalan tersebut maka akan dilakukan penelitian sebagai solusi dan memecahkan permasalahan. Untuk mengotimalkan prestasi belajar siswa, perlu diadakan situasi pembelajaran yang menyenangkan dan merangsang minat siswa untuk lebih antusias berperan aktif dalam proses pembelajaran. Untuk mengetahui perubahan ke arah yang lebih baik dipandang perlu dilakukan Penelitian. Pada penelitian ini model pembelajaran kooperatif Artikulasi. Vygotsky (Asma, 2006) menekankan bahwa "children's cognitive development is promoted and enhanced trough they interactions with more advancet and capable individuals". Pada seting belajar kooperatif, siswa dihadapkan pada proses berpikir teman sebaya mereka. Model ini tidak hanya menciptakan belajar terbuka untuk seluruh siswa, sehingga terjadi interaksi yang baik antara sesama siswa dan juga antara guru dan siswa. Dengan menerapkan model ini diharapkan tujuan pembelajaran dapat tercapai optimal, yaitu khususnya pada mata pelajaran IPA sesuai dengan standar ketuntasan minimal 73,00, karena dengan model pembelajaran kooperatif Artikulasidengan berpegang teguh dengan paradigma pembelajaran kontruktivistik. Siswa dapat melakukan pembelajaran yang meraka inginkan dan tidak hanya didominasi oleh ceramah guru dengan melalui media audio visual yang membuat siswa sangat antusias dalam belajar.

Model pembelajaran artikulasi merupakan model pembelajaran yang menekankan pada konsep siswa aktif. Siswa dibagi kedalam kelompok kecil berpasangan, satu siswa 
bertugas mewawancarai siswa lain mengenai materi yang disampaikan oleh guru, hal ini dilakukan bergantian. Kemudian tiap kelompok menyampaikan hasil kegiatan kelompok kepada kelompok yang lain.

Model artikulasi adalah model pembelajaran yang menekankan pada aspek komunikasi kelompok berpasangan dengan teman sebagai sumber belajar. Pada model ini terjadi proses interaksi antar anggota, salah satu anggota menjadi narasumber sementara yang lain merekam informasi, dan selanjutnya bergantian. Kemudian hasil belajar tersebut didiskusikan dengan kelompok lain sehingga kelompok lain juga mendapat informasi serupa. Jadi, pada model ini terjadi pembelajaran dari siswa untuk siswa

\section{Metode Penelitian}

Penelitian ini dilaksanakan di SMP Negeri 2 Blahbatuh yang beralamat di Jalan Tukad Pakerisan, Desa Keramas, Kecamatan Blahbatuh, Gianyar.

Penelitian yang dilakukan termasuk penelitian tindakan. Oleh karenanya, rancangan yang khusus untuk sebuah penelitian tindakan sangat diperlukan. Peningkatan diri untuk hal yang lebih baik ini dilakukan terus menerus sampai tujuan tercapai (Suharsimi et al., 2006). Adapun gambar dari siklus PTKnya adalah sebagai berikut.

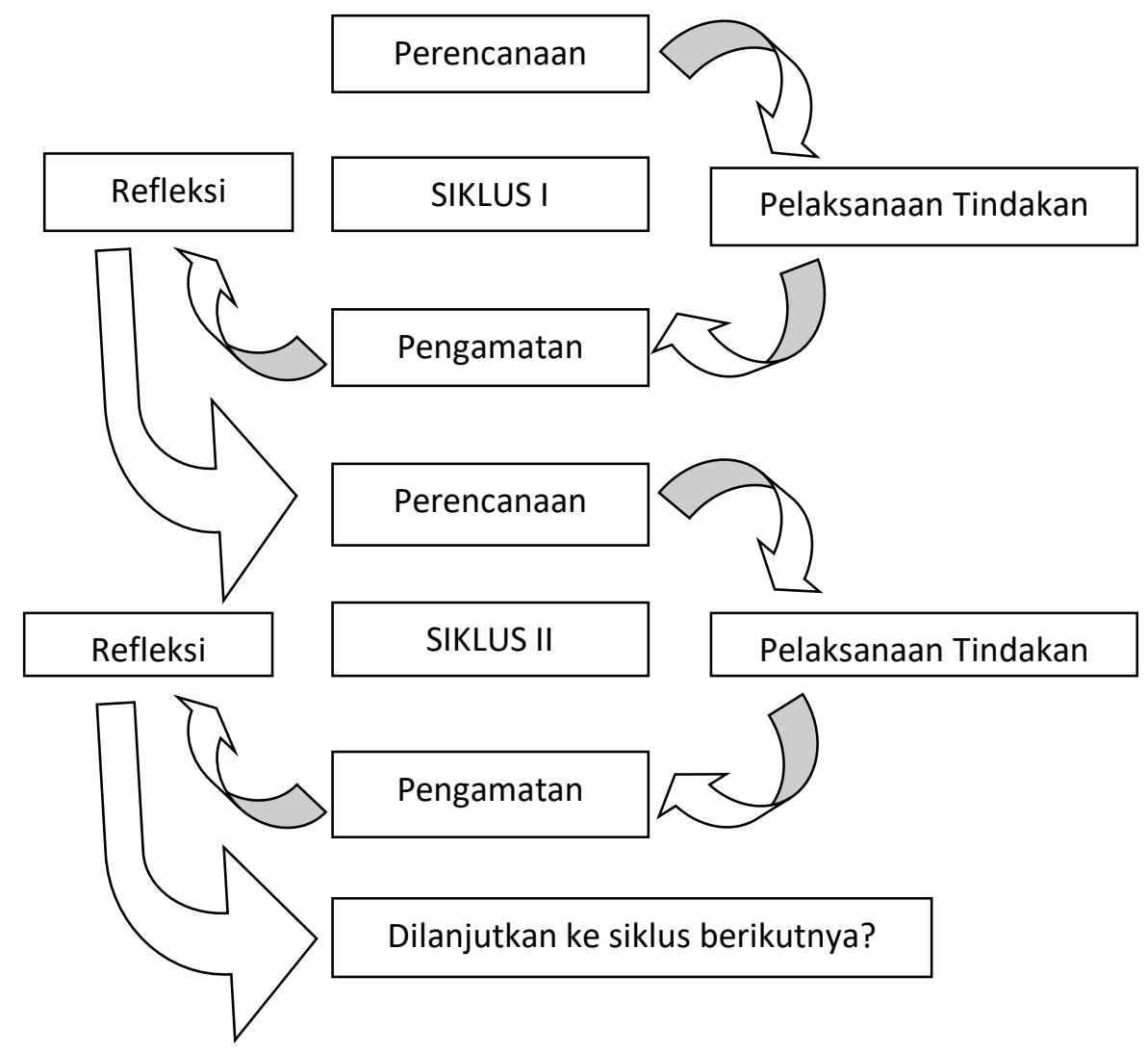

(Arikunto, 2010)

Gambar 01: Gambar Rancangan Penelitian Tindakan Kelas

\section{Siklus I}

Berdasarkan bagan, tahapan kegiatan penelitian dapat dijelaskan sebagai berikut:

\section{Perencanaan Tindakan}

Adapun perencanaan yang dilakukan untuk melaksanankan penelitian tindakan kelas adalah sebagai berikut.

1) Berkoordinasi dengan kepala sekolah untuk melaksanakan penelitian 
2) Melakukan refleksi awal dengan melihat prestasi belajar IPA siswa sebelum dilaksanakan penelitian.

3) Melakukan analisis kurikulum untuk mengetahui standar kompetensi, kompetensi dasar dan menyusun silabus yang disampaikan kepada siswa dengan menggunakan model pembelajaran Artikulasi dengan metode bimbingan individu dan kelompok.

4) Menyusun Rencana Pelaksanaan Pembelajaran (RPP) dilengkapi LKS yang dirancang. Langkah-langkah pembelajarannya diarahkan pada model pembelajaran Artikulasi dengan metode bimbingan individu dan kelompok untuk materi yang diajarkan.

5) Menyusun lembar penilaian dan tes/evaluasi berupa tes prestasi belajar dan kuesioner motivasi belajar.

6) Membuat ringkasan materi yang dibahas.

7) Membuat instrumen untuk penelitian tindakan kelas berupa lembar refleksi.

2. Pelaksanaan Tindakan

Dalam pelaksanaan ini disusun sesuai dengan tahap pelaksanaan penerapan model pembelajaran Artikulasi dengan metode bimbingan individu dan kelompok dalam mata pelajaran IPA untuk mengetahui prestasi belajar siswa. Pada setiap siklus penelitian terdiri dari 4 kali pertemuan. 3 kali pertemuan untuk melaksanakan proses pembelajaran dan 1 kali pertemuan untuk melaksanakan evaluasi atau tes prestasi belajar dan mengukur motivasi belajar siswa. Langkah-langkahnya adalah sebagai berikut.

1) Persiapan pada awal pembelajaran

Pada tahap ini, kegiatan yang dilaksanakan adalah mempersiapkan perangkat pembelajaran, membentuk kelompok learning komunity, menetukan skor awal, mengatur tempat duduk dan melakukan kegiatan apersepsi.

2) Pelaksanaan pembelajaran

Langkah-langkah dalam pelaksanaan tindakan ini adalah dilaksanakan sesuai dengan Rencana Pelaksanaan Pembelajaran (RPP) yang telah disusun dan disiapkan dengan menerapkan tahap-tahap model pembelajaran Artikulasi dengan metode bimbingan individu dan kelompok.

3. Observasi / Evaluasi

Pada pertemuan ke 4, guru melaksanakan tes prestasi belajar dan mengukur motivasi belajar siswa. Kegiatan yang dilakukan pada tahap evaluasi yaitu memberikan lembar tes evaluasi kepada siswa yang bertujuan untuk mengetahui prestasi belajar siswa dan kuesioner motivasi belajar untuk mengetahui tingkat motivasi belajar siswa setelah dilaksanakannya pembelajaran dengan model pembelajaran Artikulasidengan metode bimbingan individu dan kelompok. Hasil evaluasi akan menjadi acuan bagi peneliti dalam merancang pembelajaran pada siklus berikutnya (siklus II).

4. Refleksi

Refleksi ini dilakukan untuk melihat dan mengkaji hasil tindakan pada siklus I mengenai prestasi belajar IPA dan motivasi belajar siswa. Hasil kajian tindakan siklus I ini, selanjutnya dipikirkan untuk dicari dan ditetapkan beberapa alternatif tindakan baru yang diduga lebih efektif untuk meningkatkan prestasi belajar IPA. Alternatif tindakan ini ditetapkan menjadi tindakan baru pada rencana tidakan dalam penelitian.

Metode yang digunakan untuk menganalisis data hasil penelitian ini adalah metode deskriptif. Untuk data kuantitatif dianalisis dengan mencari mean, median, modus, membuat interval kelas dan melakukan penyajian dalam bentuk tabel dan grafik.

Indikator keberhasilan penelitian yang diusulkan dalam penelitian ini pada siklus I dan siklus II mencapai nilai rata-rata minimal 74,00 dengan ketuntasan belajar minimal $85 \%$.

\section{Hasil Dan Pembahasan}

Menurut (Mustain, 2010) artikulasi adalah apa yang kita definisikan sebagai strukturstruktur dalam otak yang melibatkan kemampuan bicara (area kemampuan bicara), membaca atau pemprosesan kata lainnya dan area gerak tambahan (menulis, membuat sketsa, dan 
gerak-gerak ekspresif lainnya). Artinya, artikulasi merujuk kepada apa-apa saja yang berkaitan dengan berbicara atau melakukan sesuatu akibat dari pemprosesan hasil kerja otak. Penerapan model artikulasi dalam pembelajaran juga melibatkan kemampuan berbicara serta gerak ekspresi akibat kegiatan berpikir siswa. Model artikulasi berbentuk kelompok berpasangan, di mana salah satu siswa menyampaikan materi yang baru diterima kepada pasangannya kemudian bergantian, presentasi di depan kelas perihal hasil diskusinya dan guru membimbing siswa untuk memberikan kesimpulan.

Model pembelajaran artikulasi prosesnya seperti pesan berantai. Artinya apa yang telah diberikan guru, seorang siswa wajib meneruskan menjelaskannya pada siswa lain (pasangan kelompoknya). Hal ini merupakan keunikan model pembelajaran artikulasi. Siswa dituntut untuk bisa berperan sebagai penerima pesan sekaligus berperan sebagai penyampai pesan (Ngalimun, 2012). (Huda, 2013) menjelaskan bahwa pembelajaran artikulasi merupakan model pembelajaran yang menuntut siswa aktif dalam pembelajaran. Pada pembelajaran ini, siswa dibagi ke dalam kelompok- kelompok kecil yang masing-masing anggotanya bertugas mewawancarai teman kelompoknya tentang materi yang baru dibahas. Skill pemahaman sangat diperlukan dalam model pembelajaran ini.

Penerapan penerapan model pembelajaran Artikulasi dengan metode bimbingan individu dan kelompok bertujuan untuk memberikan pembaruan pada kegiatan pembelajaran yang awalnya hanya didominasi oleh metode ceramah, tanya jawab, dan penugasan dan cenderung rutin dilaksanakan oleh guru. Pada pembelajaran konvensional tersebut siswa tidak mempunyai kesempatan untuk menyampaikan respon atas stimulus yang diberikan guru. Sebelum diterapkan model pembelajaran Group Investigatiion dengan metode bimbingan individu dan kelompok, terlebih dahulu dilakukan refleksi awal untuk mengetahui nilai prestasi belajar IPA siswa Kelas VII F SMP Negeri 2 Blahbatuh semester II. Berdasarkan refleksi awal, prestasi belajar siswa berada pada kategori rendah, masih banyak siswa belum mencapai Kriteria Ketuntasan Minimal (KKM) yang ditetapkan sekolah yaitu 73.00. Rata-rata awal yang diperoleh hanya mencapai 62,82 dengan ketuntasan belajar $28,20 \%$. Hal ini terjadi karena pembelajaran yang berlangsung hanya bersifat konvensional. Sehingga siswa merasa bosan dan kesulitan dalam menerima pembelajaran. Oleh karena itu peneliti melakukan upaya untuk meningkatkan prestasi belajar siswa dengan mengubah sistem pembelajaran.

Harapan peneliti terkait prestasi belajar siswa belum terpenuhi pada siklus I walaupun model pembelajaran Artikulasi dengan metode bimbingan individu dan kelompok sudah diterapkan sesuai dengan skenario dan rancangan yang telah disusun. Hal ini dikarenakan adanya beberapa hal yang menjadi kendala dalam proses pembelajaran. Kendala-kendala pada siklus I meliputi: (1) Kegiatan awal pada proses pembelajaran belum optimal dalam menarik minat siswa serta kurang mengaitkan dengan topik yang akan dibahas. (2) pada fase mengidentifikasi topik siswa masih belum menunjukkan kemandirian dan kreatifitas dalam berpikir. (3) siswa kurang optimal dalam mengumpulkan informasi melalui sumber belajar yang tersedia. (4) siswa belum terbiasa membuat kesimpulan secara individu dan kurang berani menyampaikan hasil kerjanya.

Hasil refleksi pada siklus I dikaji dengan cermat sehingga dapat digunakan untuk mengoptimalkan hasil penelitian. Kendala-kendala pada siklus I dapat diatasi dengan bantuan dari berbagai pihak diantaranya: (1) Pada awal pembelajaran perhatian siswa ditarik tertarik dengan pertanyaan awal yang ditunjukkan guru. (2) Kemampuan siswa dalam mengidentifikasi topik dilatihkan dengan cara melibatkan peran serta guru dalam fase tersebut, sehingga siswa memiliki pentunjuk dalam mengembangkan pemikirannya. (3) Siswa diberikan keleluasaan untuk mempergunakan media ausio visual, guru berulang-ulang menampilkan media sesuai permintaan siswa. (4) Guru memberikan penjelasan pada siswa agar berani dan pecaya diri untuk menyampaikan hasil kerjanya. Guru membangun suasana belajar yang demokratis dan tetap terarah pada tujuan pembelajaran. Hal ini bertujuan agar siswa mampu mengembangkan pengetahuannya melalui unjuk argumen dengan rekannya, dan mengembangkan kemampuan berpikir tingkat tinggi.

Beberapa perbaikan pembelajaran yang dilakukan dapat meningkatkan prestasi belajar pengetahuan IPA pada siklus I menjadi 72,30 yang tergolong pada kategori tinggi dan tingkat ketuntasan siswa secara klasikal sebesar 58,97\% Motivasi belajar siswa juga 
meningkat pada siklus II ketingkat 82,69 dengan ketuntasan belajar mencapai $100 \%$ dan tergolong pada kategori tinggi.

Berdasarkan hasil analisis tersebut dapat disimpulkan bahwa prestasi belajar IPA siswa Kelas VII F SMP Negeri 2 Blahbatuh pada semester II tahun pelajaran 2019/2020 dapat ditingkatkan melalui penerapan model pembelajaran Artikulasi dengan metode bimbingan individu dan kelompok.

Hasil penelitian ini sesuai dengan penelitian yang dilakukan oleh Agustini (2014) dengan judul Pengaruh Model Pembelajaran Artikulasi Berbantuan Media Kartu Gambar Untuk Meningkatkan Kemampuan Bahasa Anak TK. Hasil analisis data menunjukan bahwa terjadi peningkatan kemampuan bahasa anak pada siklus I sebesar $59,06 \%$ yang berada pada kategori rendah ternyata mengalami peningkatan pada siklus II menjadi $85,62 \%$ yang berada pada kategori tinggi. Ada peningkatan kemampuan bahasa anak sebesar $26,56 \%$ setelah menerapkan pembelajaran dengan menggunakan model artikulasi berbantuan media kartu gambar. Jadi, dapat disimpulkan bahwa model pembelajaran artikulasi berbantuan media kartu gambar dapat meningkatkan pengembangan kemampuan bahasa anak.

\section{Simpulan}

Dari penelitian yang telah dilakukan dapat disimpulkan bahwa penggunaan model pembelajaran Artikulasi dengan metode bimbingan individu dan kelompok dapat secara efektif meningkatkan prestasi belajar IPA siswa kelas VII F semester II SMP Negeri 2 Blahbatuh tahun pelajaran 2019/2020.

\section{Daftar Pustaka}

Agustini, Ni Luh Eni. 2014. Pengaruh Model Pembelajaran Artikulasi Berbantuan Media Kartu Gambar Untuk Meningkatkan Kemampuan Bahasa Anak TK. e-Journal PG-PAUD Universitas Pendidikan Ganesha Jurusan Pendidikan Guru Pendidikan Anak Usia Dini (Volume 2 No 1 Tahun 2014).

Arends, Richard I. 2004. Learning to Teach. Sixth Edition. New York: McGraw-Hill.

Asikin dan Pujiadi. Lembaran Ilmu Kependidikan Jilid 37, NO. 1, Juni 2008. Pengaruh Model Pembelajaran IPA Artikulasi Berbantuan Cd Interaktif Terhadap Kemampuan Pemecahan Masalah Pada Siswa Kelas X SMA Negeri 1 Semarang. FMIPA Unnes.

Asma, Nur. 2006. Model Pembelajaran Kooperatif. Jakarta: Depdiknas.

Buchori, 2012. Artikel Hasil Penelitian. Pengaruh Model Pembelajaran IPA Artikulasi Berbantuan Software GeogebraTerhadap Kemampuan Pemecahan Masalah Pada Siswa SMA. Fakultas Pendidikan IPA Dan IImu Pengetahuan Alam. IKIP PGRI Semarang.

Dimyati \& Mudjiono. 1994. Belajar dan Pembelajaran. Jakarta : Direktorat Jenderal Pendidikan Tinggi.

Rahman, B. 2009. Perbandingan Kemampuan Koneksi Matematik Siswa yang Pembelajarannya Menggunakan Model Artikulasi dengan Siswa yang Pembelajarannya Menggunakan Model Konvensional. Skripsi. FPMIPA UPI. Bandung. 